\title{
A SHORT REVIEW ON THE BIOLOGICAL CHARACTERISTICS OF THE SPECIES ESOX LUCIUS, LINNAEUS, 1758 IN CASPIAN SEA BASIN (IRAN)
}

\author{
Navid EBRAHIMZADEH KOUCHESFAHANI * \\ and Mohammad FOROUHAR VAJARGAH **
}

* University of Guilan, Faculty of Natural Resources, Department of Fisheries, IR-43619-96196, P. O. Box 1144, Sowmeh Sara, Iran, navid_ebrahimzadeh_k@yahoo.com, ORCID: 0000-0001-8306-9879.

** University of Guilan, Faculty of Natural Resources, Department of Fisheries, IR-43619-96196, P. O. Box 1144, Some Sara, Iran, mohammad.forouhar@yahoo.com (c.a.), ORCID: 0000-0002-6637-6612.

KEYWORDS: Northern Pike, Caspian Sea basin, biology.

DOI: 10.2478/trser-2021-0006

\section{ABSTRACT}

The Esox genus belongs to the family Esocidae. It is a freshwater fish that can be found in different parts of Europe, Asia, and North America. The Northern Pike, is a carnivorous fish, member of the only remaining genus of the Esocidae. This fish prefers to lead a solitary life due to the disadvantages of the presence of individuals of the same species which compete for food resources and territory. Waiting for a suitable situation to catch prey is a favoured hunting method, which means this specific species is a lie-in-wait predator. The elongated body and the broad snout are the most striking features used for the identification of this species. This lie-in-wait carnivorous predator mostly feeds on invertebrates and fishes. The species spawns annually. The special living conditions of this species and their endangered environment have made it necessary to avoid any acts that can affect their life quality.

ZUSAMMENFASSUNG: Eine kurze Überprüfung der biologischen Merkmale des Hechtes Esox lucius, Linnaeus 1758 im Becken des Kaspischen Meeres (Iran).

Esox, eine gattung aus der familie der Esocidae, ist ein süßwasserfisch, der in verschiedenen teilen Europas, Asiens und Nordamerikas vorkommt. Seine arten werden hecht genannt und in akademischen studien als Esox lucius bezeichnet. Der hecht ist ein fleischfressender fisch und gehört zur einzigen verbliebenen gattung der Esocidae. Dieser fisch zieht es vor, allein zu leben, da die gleichen arten wie die gegenseitigen nahrungsressourcen und das territorium die nachteile aufweisen, die zu unterschiedlichen herausforderungen führen können. Das warten auf eine geeignete situation, um die beute zu jagen, ist ein häufiges verhalten, was bedeutet, dass diese spezielle art ein raubtier ist, das auf der lauer liegt. Langer körper und breite schnauze sind merkmale und eigenschaften dieses fisches, die einen unterschied deutlich machen.

REZUMAT: O scurtă revizuire asupra caracteristicilor biologice ale speciei Esox lucius Linnaeus, 1758, în bazinul Mării Caspice (Iran).

Genul Esox aparține familiei Esocidae, fiind reprezentat de pești de apă dulce răspândiți în diverse părți ale Europei, Asiei și Americii de Nord. Știuca este un pește carnivor, membru al singurului gen existent în familia Esocidae. Peștele duce o viață solitară, date fiind dezavantajele prezenței indivizilor din aceeași specie în ceea ce privește competiția pentru hrană și teritoriu. Obișnuiește să aștepte momentul oportun pentru atacarea prăzii, fiind un prădător de ambuscadă. Corpul alungit și rostrul larg sunt trăsăturile distinctive folosite pentru identificarea speciei. Hrana principală o reprezintă nevertebratele și peștii. Specia depune icre anual. Condițiile de viață deosebite și mediul de viață aflat într-un echilibru precar fac acest pește foarte vulnerabil față de acțiunile ce i-ar putea afecta calitatea vieții. 


\section{INTRODUCTION}

The fish species of economic and ecological value and their habitats are generally threatened all over the world (Forouhar Vajargah et al., 2019; Kar and Khynriam, 2020; Reynaldo de la Cruz et al., 2020; Curtean-Bănăduc et al., 2020; Scheuerell et al., 2020; Koster et al., 2020), new, updated and variable research about them being highly needed for proposals of better management practices. (Sattari, 2020).

Esox lucius is considered a fish species of economic and ecological importance

The wide distribution and special behaviour of this fish have led to much research in the field of nutrition, physiology, behaviour, and habitat (Sattari, 2020).

The present research is a short review of information obtained from various researches and provides essential information about the behaviour and biological characteristics of this fish, especially in the Caspian Sea basin. Specific information relating to the Anzali wetlands, connected environments, and ecological problems, associated with these areas are provided.

The Northern Pike is a fish of the order Esociformes. Esox lucius Linnaeus, 1758 was firstly introduced from Europe (Coad, 2016). This fish is one of the widely distributed species that can be found in most of the aquatic ecosystems (Rodger, 1991).

The pikes can be found in the fresh waters of the northern hemisphere. Their size can vary from medium to large (40-50 $\mathrm{cm}$ up to $1.4 \mathrm{~m}$ ).

In a single genus, Esox, seven species are recognized, in Iran, the species Esox lucius Linaeus exists (Coad, 1987; Eschmeyer and Fong, 2016).

\section{Morphology}

Elongated body, big partly scaled head, broad snout, huge mouth which covers half of the head, with many large and sharp teeth, convex upper jaw and a dorsal fin which is in front of the anal fin are the characteristics of this fish (Berg, 1948) (Figs. 1 and 2).

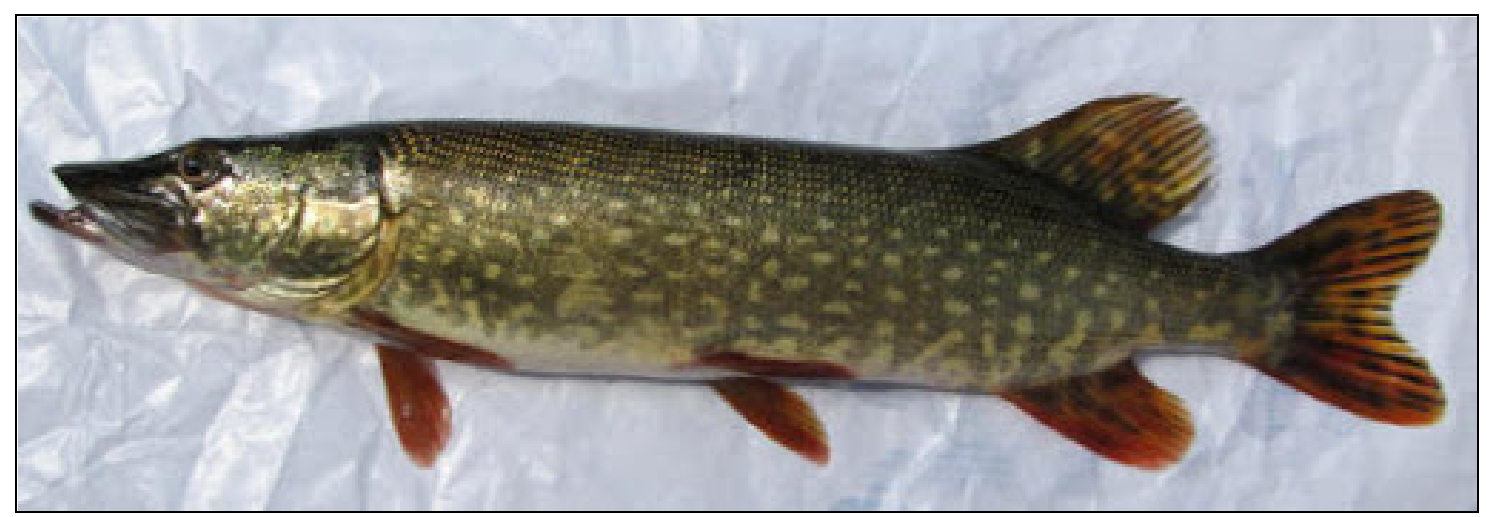

Figure 1: Esox lucius Linnaeus, 1758 (Coad, 2016).

The dorsal fin has 15 to 19 rays that can be divided into six to 10 branched and 13 to 18 unbranched rays. In addition, 12 to 16 anal rays, 11 to 17 pectoral rays and seven to 13 rays can be seen. Lateral line scales can be counted from 105 to 148. (Coad, 2016) 


\section{Colour}

Generally, the skin is olive-green with light yellow spots which is darker on the back and becomes lighter and eventually fades over the belly. Yellow to white spots can be seen on the sides. Scales can also be recognized from the golden tips. Wavey head and golden or yellow eyes are noticeable. All fins, except pectoral and pelvic, are green, yellow, orange or red with the exception of black or dusky to orange spots (Coad, 2016).

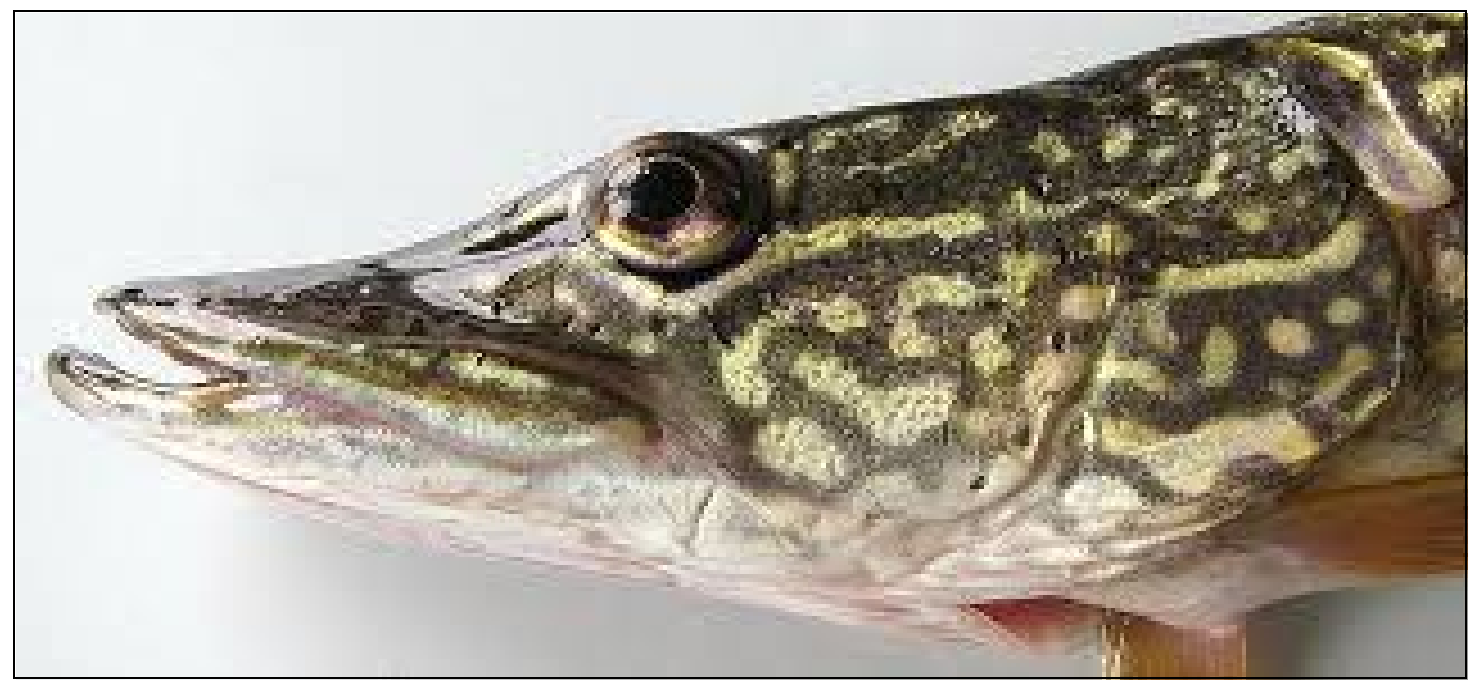

Figure 2: Esox lucius Linnaeus, 1758, head (Coad, 2016).

\section{Habitat}

E. lucius can be seen in various parts of Northern Hemisphere such as Europe, North America, and Asia including Iran (Sattari, 2020).

This lie-in-wait predator lives solitarily and prefers to live in any stagnant or slow flowing water such as marshes, ponds, lagoons, etc. E. lucius can also be seen only in the lower reaches of rivers (Sattari, 2020). The Siah Keshim protected wetland, a part of the Anzali Wetlands (Fig. 3) in northern Iran, Caspian Sea basin, is known as one of the habitats of the E. lucius (Riazi, 1996). The Amir Kalayeh, Anzali, and Boojagh wetlands (all from the Caspian Sea basin, north of Iran) are habitats for E. lucius as well.

The Siah Keshim aquatic ecosystem is located in the south-west of the Anzali wetlands and has been designated as a protected area since 1968 due to its value as a shelter for migratory birds. The Siah Keshim land area spans from Mahruzeh in the North, the Anzali wetlands, and Siah Darvishan River in the East, Ziabar and Mazaranmahale villages, and Southern farms of Vishka in the West, and Laksar in the South. (Asri and Eftekhari, 2002)

Geologically, this wetland is very young, and its climate is influenced by the seamountain system. The rainfall is very high, with little annual change and the temperature fluctuations almost constant. (Asri and Eftekhari, 2002)

The average annual rainfall of the area is $1,686.5 \mathrm{~mm}$, the average maximum temperature of the hottest month of the year is $33.9 \mathrm{C}^{\circ}$ and the average minimum temperature of the coldest month of the year is $-1.2 \mathrm{C}^{\circ}$ and the average annual relative humidity is $85 \%$. The dry season in this area is very brief and the area falls in the temperate climate. (Asri and Eftekhari, 2002) 
In general, six main rivers flow into this lagoon which are, from south-west to northeast, the Gaz, Masouleh Roodkhaneh, Zagheh, Palangavar, Khalkii, and Morghak. There are also canals and drainage channels, the most important of which is Mahruzeh. (Asri and Eftekhari, 2002)

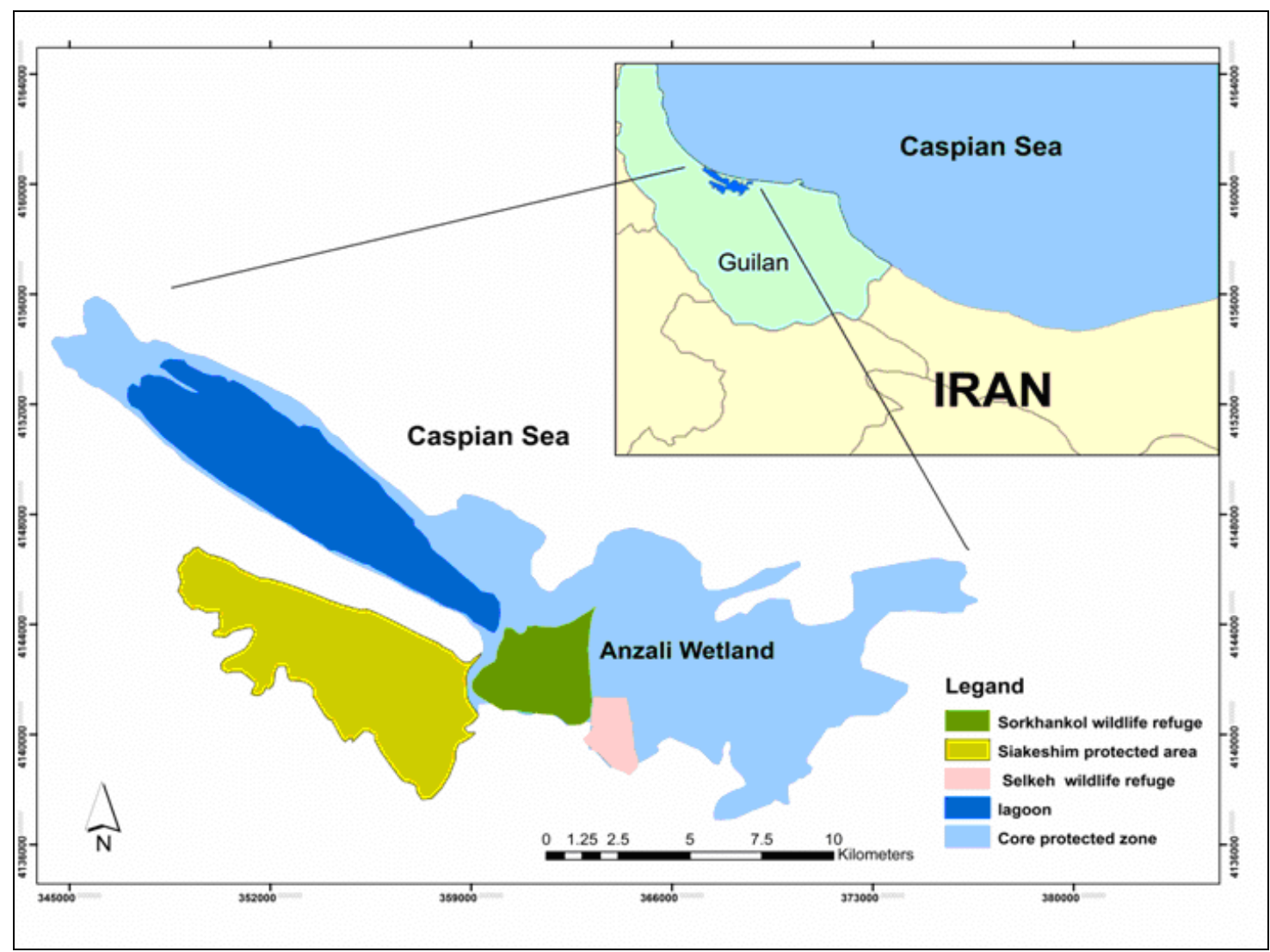

Figure 3: Anzali Wetland.

\section{Anzali wetland}

The Caspian Sea, the largest lake in the world (Forouhar Vajargah et al., 2018), is facing ecological problems such as discharge of industrial and agricultural effluents and growing urbanization in most riparian areas of the Caspian Sea (Sattari et al., 2020). As a connected environment, Anzali wetlands has similar ecological problems (Vesali Naseh et al., 2021).

Increasing anthropogenic activities such as overpopulation, industrial, and agricultural activities presence have led to a decrease in water quality of the Anzali wetlands (Nasirian, 2007).

At the southern end of the Caspian Sea, a globally important wetland is located, namely the Anzali Wetland, a suitable habitat to numerous aquatic and aquatic-dependent organisms including fishes, invertebrates, birds, etc. (Khosravi et al., 2011)

E. lucius or in local dialect, "Shook" (in Farsi), is an old native species of the Anzali wetlands that is still able to continue living and reproducing despite the fact that this wetland is facing different environmental problems. The pike is one of the most popular fish for sport fishing in the Guilan Province, North of Iran. 


\section{Food}

E. lucius fingerlings prey on zooplanktons and insects, whereas adults prey on fish, mice, ducklings, and frogs. It is noticeable that both male and female stop eating during spawning (Orlova and Popova, 1976).

To be more specific, the results from research based on the E. lucius in Boojagh Wetland showed that the pike's diet includes 13 different types of food: among which dragonfly larvae (14\%), pipefish (13.8\%), and goby (13.4\%), have the highest frequency percentage amongst all prey (Nezami et al., 2005).

\section{Hunting}

Their highly mobile eyes enable them to find prey in nearly any direction and their sighting grooves on the snout helps them to estimate depth and distance more effectively. A sudden explosion-like movement will lead to food capture. Fish with cylindrical bodies are preferred by E. lucius as they are easier to swallow. The whole process can be divided into eye movement towards the prey, turning the body to a suitable direction, chasing, attacking, capture, placing the head of the prey in mouth, and swallowing stages. Fish with one-third to one-half the length of the pike are normally picked. (Coad, 2016)

\section{Reproduction}

Evaluation and assessment of physiological condition and size is essential to artificial breeding and to providing the best growth condition for fish resource maintenance (Zaprudnova and Prozorovskaya, 1999).

Based on academic studies, it can be claimed that E. lucius has an annual winter spawning and that the gonadal development process happens through the spring. After spawning, gonads start developing again and in summer, yolk granules could be seen with a vacuole from spring. Furthermore, yolk production is complete in mid-autumn and spawning takes place in winter (Epler et al., 2008).

\section{Threats and diseases}

Many studies have proved a high level of infestation in pike. Research showed helminths were found within the ratio of $78.9 \%$ (Eslami et al., 1972). Encounter with the digenetic trematode, Rhipidocotyle illense (Ziegler, 1883), the nematode larva, Eustrongylides excisus Jägerskiöld, 1909, and Acanthocephalus lucii (Müller, 1776) was recorded (Mokhayer, 1976). The presence of Eustrongylides excisus was again reported in 2002 and 2004 (Sattari et al., 2020). This consistency is worthy of attention, noticing the fact that this parasite can damage muscle tissue thus making it an unlucrative commercial item (Coad, 2016). Diplostomum spathaceum Rudolphi, 1819, an eye parasite was also found in E. lucius (Barzegar et al., 2008)

In an examination on the pikes of the Amir Kalayeh wetlands in Guilan, Iran, the following parasites were recorded: Eustrongylides excisus, Triaenophorus crassus Forel, 1868, Trichodina sp. Ehrenberg, 1831, Tetraonchus monenteron (Wagener, 1857), Diplostomum spatheceum, Lernaea sp. Linnaeus, 1758, Raphidascaris acus (Bloch, 1779), Camallanus lacustris (Zoega, 1776), Argulus sp. Müller, 1785, and Piscicola sp. Blainville, 1818 (Khara et al., 2004). The piscivorous diet picked by the fish was suggested as the reason for this wide variety (Khara et al., 2004). 
In light of the high economic and ecologic value, the blood parameters of the E. lucius were examined in a study in which 120 fish were tested for parasites. Their effects on blood parameters revealed that five of the 10 isolated parasites could affect blood parameters including Rhipdocotyle illense, Corynosoma strumosum (Rudolphi, 1802), Diplostomum spathaceum, Tetraonchus monenteron, Eustrongylides exisus, with the studied parameters being HCT, Hb, RBC, WBC, MCV, MCH, MCHC. (Jamalzade et al., 2014).

In addition, an analysis carried out in the Anzali wetlands showed the highest prevalence of the parasites in E. lucius was for Eustrongylides exisus (22.66\%) and the lowest was for Tricodina sp. Ehrenberg, 1831 (3.33\%) (Jamalzad et al., 2012).

The greatest average of infection severity was found for Rhypdocotyle illense (88.5\%) and the minimum was reported to be for Lernaea cyprinicea (1.75\%) (Jamalzad et al., 2012).

\section{CONCLUSIONS}

Esox lucius is an important fish to study from various aspects, including its evolution and the aquacultures which it is part of in different parts of the world. Its long olive-green body, predatory behaviour, fast movement and solitary living are known to be the most striking characteristics of this species. In addition,.

The fish is facing ecological problems in the Anzali wetlands, a famous habitat which is in the southern basin of the Caspian Sea, such as pollution that have been found in different studies and mentioned in this research.

The Northern Pike is a fish of biological importance that may need special protection in the near future due to the related problems. It can be understood that this species life conditions are changing in many ways, the Pasikhan River in Gilan, which was famous for its pikes, is an example of a river system where pike have almost vanished.

To conclude, the need for further research on this species is undeniable.

\section{ACKNOWLEDGEMENTS}

We are grateful to everyone with whom we have had the honour to work within this project. We would also like to express our gratitude to the Transylvanian Review of Systematical and Ecological Research editorial board and reviewers for giving us the opportunity of publishing this paper. 


\section{REFERENCES}

1. Asri Y. and Eftekhari T., 2002 - An introduction to the flora and vegetation of Siah-Keshim lagoon, Iran, Journal of Environmental Studies, 28, 2-3.

2. Barzegar M., Raeisi M., Bozorgnia A. and Jalali B., 2008 - Parasites of eye of fresh and brakish water fishes in Iran, Iranian Journal of Veterinary Research, Shiraz University, 9, 3, 24, 256261.

3. Curtean-Bănăduc A., Burcea A., Mihuţ C.-M., Berg V., Lyche J. L. and Bănăduc D., 2020 Bioaccumulation of persistent organic pollutants in the gonads of Barbus barbus (Linnaeus, 1758), Ecotoxicology and Environmental Safety, 201, 110852, 10., https://doi.org/10.1186/s12302-020-00348-z.

4. Berg L. S., 1948-1949 - Freshwater fishes of the USSR and adjacent countries, Program for Scientific Translations (1962-1965).

5. Coad B. W., 1987 - Zoogeography of the freshwater fishes of Iran, 213-228, in, Proceedings of the Symposium on the Fauna and Zoogeography of the Middle East, Krupp F., Schneider W. and Kinzelbach R. (eds), Mainz, 1985, Beihefte zum Tübinger Atlas des Vorderen Orients, Reihe A. (Naturwissenschaften), 28, Ludwig Reichert Verlag, Wiesbaden, 338.

6. Coad B. W., 2016 - Review on the pikes of Iran (Family Esocidae), Iranian Journal of Ichthyology, 3, 3, 161-180.

7. $\quad$ Epler P., Euszczek-Trojnar E., Socha M., Szcz-erbik P., Sokoowska-Mikoajczyk M. and Popek W., 2008 - Growth rate and histological picture of the gonads, in Pike, Esox lucius and pikeperch, Sander lucioperca, from the Tresna reservoir (Lake Ywieckie), Archives of Polish Fisheries, 16, 147-154.

8. Eslami A. H., Anwar M. and Khatiby S., 1972 - Incidence and intensity of helminthoses in pike (Esox lucius) of Caspian Sea (Northern Iran), Rivista italiana di Piscicoltura e Ittiopatologia, 7, 11-14.

9. Forouhar Vajargah M., Mohamadi Yalsuyi A., Sattari M. and Hedayati A., 2018 - Acute toxicity effect of glyphosate on survival rate of common carp, Cyprinus carpio, Environmental Health Engineering and Management Journal, 5, 2, 61-6.

8. Asri Y. and Eftekhari T., 2002 - An introduction to the flora and vegetation of Siah-Keshim Lagoon, Iran, Journal of Environmental Studies, 28, 2-3.

9. Barzegar M., Raeisi M., Bozorgnia A. and Jalali B., 2008 - Parasites of eye of fresh and brakish water fishes in Iran, Iranian Journal of Veterinary Research, Shiraz University, 9, 3, 24, 256261.

10. Forouhar Vajargah M., Bibak M., Sattari M. and Imanpour Namin J., 2019 - Review of pollutants of aquatic environments, The 4th international conference on the new horizons in the agricultural sciences, natural resources and environment, Tehran University, 1-5.

11. Jamalzad F., Khara H., Daghigh Rouhi J. and Sayyad Borani M., 2012 - Parasite infection of pike (Esox lucius Linnaeus, 1758) in the Anzali Wetland - Iran, Journal of Fisheries, 6, 1, 21, 149-164.

12. Jamalzad F., Khara H., Daghygh Rouhi J. and Sayadborani M., 2014 - Effects of parasitic infections on some hematological parameters of pike (Esox lucius Linnaeus, 1758) in the Anzali Wetland, Iranian Journal of Biology, 27, 1, 22-36.

13. Kar D. and Khynriam A. D., 2020 - On a recent pioneering taxonomic study of the fishes from Rivers Diyung, Vomvadung, Khualzangvadung, Tuikoi and Mahur in Dima Hasao District of Assam (India), Transylvanian Review of Systematical and Ecological Research, 22.3, The Wetlands Diversity, 83-106, DOI: 10.2478/trser-2020-0019.

14. Khara H., Nezami A., Jafarzadeh A., Ajang B., Satari M. and Mosavi S. A., 2004 - Occurrence and intensity of parasites from pike (Esox lucius, Linnaeus, 1758) in Amir Kelaieh Lagoon, Journal of Veterinary Research, 59, 4, 333-339. 
15. Khosravi M., Bahramifar N. and Ghasempouri M., 2011 - Survey of heavy metals (Cd, Pb, Hg, $\mathrm{Zn}$, and $\mathrm{Cu}$ ) contamination in sediment of three sites Anzali wetland, Journal of Health Environment , 4, 2, 223-232.

16. Koster W. M., Stuart I., Tonkin Z., Dawson D. and Fanson B., 2020 - Environmental influences on migration patterns and pathways of a threatened potamodromous fish in a regulated lowland river network, Ecohydrology, doi.org/10.1002/eco.2260.

17. Mokhayer B., 1976 - Fish diseases in Iran, Rivista italiana di Piscicoltura e Ittiopatologia, 11, 4, 123-28.

18. Nasirian M., 2007 - A new water quality index for invironmental contamination contributed by mineral processing: A case study of Amang (Tin Tailing) processing activity, Journal of Applied Siences, 2977-2987.

19. Nezami B. S. A., Khara H., Nikokerdar L. and Mirmosavy M., 2005 - The diet survey Zibakenar-Kiashar Bojagh Lagoon pike (Esox lucius), Journal of Agricultural Sciences and Natural Resources, 11, 4, 175-186. (in Farsi)

20. Orlova E. L. and Popova O. A., 1976 - The feeding of predatory fish, the catfish, Silurus glanis, and the pike, Esox lucius, in the Volga Delta following regulation of the discharge of the river, Journal of Ichthyology, 16, 1, 75-87.

21. Reynaldo de La Cruz E., Vega Cendejas M. E., Rodriguez Machado S., Garcia Fernández F. and Vega Torres A., 2020 - Diversity and structure of the ichthyologic communities in the diving sites in Holgun (Cuba), Transylvanian Review of Systematical and Ecological Research, 22.3, The Wetlands Diversity, 57-82, DOI: 10.2478/trser-2020-0018.

22. Riazi B., 1996 - Siah-Keshim. The protected area of Anzali Wetland, Department of the Environment, Tehran, 101. (in Farsi)

23. Rodger R. W. A., 1991 - Fish facts, An illustrated guide to commercial species be VAN 34Rodger, Newyork, 108-109.

24. Sattari M., Shafiei S., Daghigh Roohi J., Abdolahpour Biria H. and Bekhsat N., 2002 Occurrence and intensity of Eustrongylides excisus (L.) (Nematoda: Dioctophymidae) from some bony fish species in the Caspian Sea and its basin, Journal of the Faculty of Veterinary Medicine, University of Tehran, 57, 1, 37-41. (in Farsi)

25. Sattari M., Shafiei S., Daghigh Roohi J., Abdolahpour Biria H. and Bekhsat N., 2002 Occurrence and intensity of Eustrongylides excisus (L.) (Nematoda: Dioctophymidae) from some bony fish species in the Caspian Sea and its basin, Journal of the Faculty of Veterinary Medicine, University of Tehran 57, 1, 37-41.

26. Sattari M., Khara B., Roohi J. D. and Shafii S., 2004 - Occurrence and intensity of some nematodes in the bony fish species of the Caspian Sea and its basin, Biology in Asia International Conference, Singapore, 7-10 December 2004.

27. Sattari M., Bibak M. and Vajargah M. F., 2020 - Evaluation of trace elements contaminations in muscles of Rutilus kutum (Pisces: Cyprinidae) from the Southern shores of the Caspian Sea, Environmental Health Engineering and Management Journal, 7, 2, 1-2.

28. Scheuerell M. D., Ruff C. P., Anderson J. H. and Beamer E. M., 2020 - An integrated population model for estimating the relative effects of natural and anthropogenic factors on a threatened population of steelhead trout, Journal of Applied Ecology, 1-35.

29. Eschmeyer W. N. and Fong J. D., 2016 - Species by family/subfamily. (http://researcharchive.Calacademy.org/research/ichthyology/catalog/SpeciesByFamily.asp), Electronic version accessed 27 July 2016.

30. Vesali Naseh M. R., Karbassi A., Ghazaban F. and Baghvand A., 2012 - Evaluation of heavy metal pollution in Anzali Wetland, Iranian Journal of Toxicology, 5, 1-2.

31. Zaprudnova R. A. and Prozorovskaya M. P., 1999 - The change in concentrations of catecholamines and ions in tissues of Bream (Abramis brama) under stress, Jurnal of Ichthyology, 39, 262-266. 